\title{
"Eu tinha minha liberdade": entrevista de Nair Jane de Castro Lima, liderança histórica das trabalhadoras domésticas do Rio de Janeiro
}

\author{
"I had my freedom": Interview with Nair Jane de Castro Lima, historical \\ leader of the domestic workers of Rio de Janeiro
}

\section{Entrevistadores: Paulo Fontes, ${ }^{1}$ Louisa Acciari ${ }^{2}$ e Tatiane de Oliveira Pinto ${ }^{3}$ Edição: Paulo Fontes e Yasmin Getirana ${ }^{4}$ Transcrição: Yasmin Getirana}

Palavras-chave: Trabalho doméstico; sindicalismo; gênero.

Keywords: Domestic work; trade unionism; gender.

úcida, irônica e carismática, Nair Jane de Castro Lima, hoje com 87 anos, Lnos concedeu essa entrevista no dia 24 de agosto de 2017 no Centro de Documentação de História Contemporânea do Brasil (CPDOC) da Fundação Getúlio Vargas, tradicional espaço de celebração da memória das elites políticas e econômicas do país. À vontade em suas rememorações e narrativas, a pompa da instituição não intimidou essa mulher negra, trabalhadora doméstica aposentada e ainda atuante líder sindical.

Nair Jane presidiu a Associação Profissional das Empregadas Domésticas do Rio de Janeiro na década de 1970, participou de sua transformação em sindicato, do qual se tornou a primeira presidenta em 1988, e participou ativamente na construção da Central Única dos Trabalhadores (CUT). Além disso, foi uma das fundadoras da Confederação Latino-Americana e do Caribe das Trabalhadoras Domésticas (CONLACTRAHO) em 1988 e do sindicato da categoria na Baixada Fluminense, onde atualmente ocupa o cargo de vice-diretora. Em 2003, recebeu o Prêmio Bertha Lutz, do Senado Federal, e em 2019 foi homenageada com o

1 Professor do Instituto de História da UFRJ e Pesquisador Bolsista Produtividade do CNPq. E-mail: pfontes@mandic.com.br. ORCID: http://orcid.org/0000-0002-9277-6193.

2 Pós-doutoranda júnior, bolsista do CNPq no Programa de Pós-Graduação em Sociologia e Antropologia da UFRJ e pesquisadora associada ao Departamento de Estudos de Gênero da London School of Economics (LSE). E-mail: louisa.acciari1@gmail.com. ORCID: http://orcid.org/0000-0002-2335-7948.

3 Professora do Departamento de Economia Doméstica e Hotelaria da UFRural-RJ.E-mail: tatiolp@ufrrj.br. ORCID: http://orcid.org/0000-0002-9717-4597.

4 Mestranda do Programa de Pós-Graduação em História Social da UFRJ. Bolsista CAPES. E-mail: yasmingetirana@gmail.com. ORCID: https://orcid.org/0000-0002-8747-0763. 
“Diploma Mulher-Cidadã Leolinda de Figueiredo Daltro", na Assembleia Legislativa do Estado do Rio de Janeiro.

O que chama atenção na narrativa de Nair é uma trajetória rica em detalhes que articulam sua trajetória pessoal com o processo histórico e descontínuo da luta da categoria de trabalhadoras domésticas por direitos no Brasil. Além disso, destaca como as relações de trabalho no universo doméstico foram e ainda são permeadas por marcadores de classe, raça, gênero e geração, constituindo a realidade de assimetrias de poder a que essas trabalhadoras têm sido submetidas, apesar dos avanços na legislação nos últimos anos.

Como tantas outras mulheres negras, Nair Jane começou a trabalhar em casa de família ainda criança, em troca de comida e um quarto, denunciando, através de sua trajetória, o caráter servil idealizado nas relações entre famílias empregadoras e as empregadas. Mas sua história de vida também é "atípica" em vários sentidos. Além das possibilidades de estudo, Nair viajou ao exterior com as famílias que a empregaram, vivenciou realidades muito diversas, aprendeu línguas e ampliou seu repertório cultural.

Tais experiências somadas à sua atuação na Juventude Operária Católica foram fundamentais em sua militância sindical e política. Sua entrevista revela, assim, muito do processo de construção e fortalecimento do movimento nacional de trabalhadoras domésticas, que perpassa as primeiras associações até os atuais sindicatos, atravessando o período da ditadura, da democratização e dos governos do PT.

O movimento das domésticas teve origem na mobilização pela equidade de direitos, sendo impulsionado pelo grande contingente de mulheres atreladas à ocupação no serviço doméstico, mas também por meio de um jogo de forças que hoje pode estar sendo ressignificado. Em uma narrativa que demonstra resistência, agência e força, Nair nos convida a pensar em como as relações de trabalho se mantêm e se transformam, nos dando uma grande lição de organização coletiva. Na figura de Nair, retrata-se o processo lento de reconhecimento político e jurídico das domésticas como trabalhadoras, indicando a ainda frágil, mas não menos presente, construção da cidadania.

A versão completa da entrevista está disponível no acervo do setor de História Oral do CPDOC-FGV, no Rio de Janeiro.

\section{Paulo Fontes, Louisa Acciari, Tatiane de Oliveira Pinto e Yasmin Getirana.}

\section{A senhora poderia falar seu nome completo, local e data de nascimento?}

Meu nome é Nair Jane de Castro Lima, eu sou da cidade de Imperatriz, no Maranhão. Nasci no dia 15 de abril de 1932.

\section{O que os pais da senhora faziam lá em Imperatriz?}

Meu pai era empregado de uma fazenda. Com 5 anos eu saía de madrugada com meu pai pra candiar boi. Aí ele foi trabalhar em uma estrada de ferro, e a gente passou a viver que nem nômade. A gente passava um tempo em um lugar, um tempo em outro. Eu tinha 16 irmãs e um irmão. E nós não somos todos do Maranhão. Do Maranhão, acho que tem umas três. Depois veio São Paulo, Minas Gerais, Rio de Janeiro. Minas Gerais foi o lugar em que a gente ficou mais tempo. As famílias paupérrimas como a minha, que não tinham condição de educar toda 
aquela criançada, então começavam a "distribuir". Fui parar lá em Minas Gerais, em São José de Além Paraíba, e lá eu fui para um orfanato. Nessa altura eu estava com quase 9 anos. E lá, quando uma família foi visitar o orfanato, comecei a brincar com os dois filhos da família, e as crianças na hora de ir embora queriam me levar. Então, a superiora falou que não podia, que eu tinha que ficar lá. Ela disse assim: "Ah, pra levar tem que pôr numa escola". E aí, a minha primeira patroa me registrou na Escola Luiza de Castro, na Tijuca, e eu fui trabalhar no Rio de Janeiro. Eu tomava conta daquelas duas crianças. Eu tinha 9 anos, a menina tinha 6 e o menino 5. Eles estudavam numa escola que não era muito distante da minha, então eu os levava de manhã, colocava na escola e ia para minha. Quando minha aula terminava, eu voltava, pegava-os na escola e às vezes ainda brincava com as crianças do colégio deles quando a aula ainda não havia terminado. Eu tinha 9 anos. Usava um banquinho pra fazer o mingau das crianças, porque eu não conseguia alcançar o fogão, que era alto. E ali eu trabalhei 11 anos por casa, comida e roupa. E eu digo pra todo mundo: tudo que eu aprendi na vida, aprendi naquela casa. Eu estudei, aprendi a fazer arte culinária em uma organização chamada SAPS, ${ }^{5}$ na Praça da Bandeira.

A senhora acha que quando eles foram lá no orfanato onde a sra. estava, eles foram buscar uma babá?

Não, pelo menos a impressão que eu tive não era essa, não. Eles visitavam pra levar doações, levar roupas para as crianças. Eles iam sempre lá, mesmo depois que eu já estava no Rio. E como os filhos deles, na hora de ir embora, queriam me levar e começaram a chorar, uns dez dias depois eles voltaram com a proposta de me trazer...

Eles pensaram e falaram "vai ser bom ter alguém"?

É, de trazer a neguinha pra cá [pro Rio]...

Como eram os nomes dos seus primeiros patrões? O que faziam?

Roberto Bastos e Glorinha Beuttenmüller. ${ }^{6}$ Ela era fonoaudióloga e o meu patrão trabalhava numa coisa do governo. Não sei bem em quê ele trabalhava.

\section{Como era o cotidiano do seu trabalho?}

[Eu dormia num] quarto onde tinha três camas. A cama da Vânia, a do Antônio Frederico [os filhos dos meus patrões] e a minha era no meio dos dois. Como todos eram crianças - eu só tinha 9 anos -, a gente ficava junto o tempo todo. Eles tinham uma avó que tinha uma casa grande, na rua Guapiara. Tinha uma criançada na rua e a gente reunia aquela criançada na casa dela. Um dia, ela disse pra minha patroa: "Olha só, essa babá que você arranjou aí é maluca. Ela traz todas essas crianças pra cá, elas ficam estudando e ela faz lanche pra todo mundo". Tinha uma mesa enorme de cimento e a gente ficava ali. Eu só cuidava das crianças. Isso eu vou dizer. Quando eu vejo muitas colegas falarem dos patrões, eu digo, “olhe,

5 Restaurantes populares que ofereciam refeições aos trabalhadores a baixo custo e que pertenciam a uma rede de alimentação vinculada à Previdência Social entre os anos de 1940 a 1967, com sede no Rio de Janeiro.

6 Maria da Glória Cavalcanti Beuttenmüller é escritora e fonoaudióloga. Desenvolveu o método conhecido como "Terapia da Fala", utilizado por jornalistas e radialistas de diversas emissoras brasileiras. Publicou mais de seis livros e atualmente leciona na CAL - Faculdade de Artes Cênicas, no Rio de Janeiro. Do casamento com Roberto Bastos, de quem há bem menos informações disponíveis, teve Vânia Maria Beuttenmüller Bastos e Antônio Frederico Beuttenmüller Bastos. 
tudo que eu sou aprendi naquela casa e eu só cuidava das crianças, eu não lavava nem a minha roupa".

\section{Eles Ihe chamavam como?}

As crianças e os pais me chamavam de Bá. Eu não tinha outro nome. Nair Jane não existia, era Bá. Bá de babá.

\section{E em qual momento a senhora tinha tempo de estudar?}

Eu levava as crianças pro colégio, que era ali no Braga Carneiro, e ia pro meu, que era no Luiza de Castro. Quando a minha aula terminava, eu pegava eles e trazia pra casa. Eu estudava quase que no mesmo horário; e no sábado, quando meu patrão ia pegar, ele corrigia os deveres, o meu também. Então, eu digo que tudo que eu aprendi, eu devo a eles. $\mathrm{E}$ a mãe da minha patroa, a dona Laura, me matriculava em tudo que era cursinho, de aprender bordado, de tricô... E como eles eram católicos como eu, fui fazer catequese, e acabei entrando na JOC.7 Eu não tinha dinheiro, mas tinha tempo pra fazer essas coisas. Dinheiro não tinha. Quando eu ia pra um cinema, eu recebia o dinheiro do cinema. Só isso. Quando eu queria roupa, eles me levavam na loja e eu escolhia a roupa. Só isso. E eu vivia uniformizada...

\section{Havia outras empregadas domésticas na casa?}

Tinha a cozinheira, a Totonha, que tinha ido pra casa deles na noite que eles casaram. Ela já estava velha. [Quando] eles queriam contratar uma empregada, se a Totonha dissesse assim "ah, essa não serve", não servia mesmo! Tinha a lavadeira - que lavava e passava a roupa de todo mundo, inclusive de todos os empregados: a copeira, a arrumadeira e uma faxineira que ficava mais tempo na casa, porque a casa era muito grande. E nessa casa tinha uma coisa que eu não vi em nenhuma outra casa no Brasil. Embaixo tinha os quartos de todos os empregados, como é nos EUA. Então, cada pessoa tinha o seu quarto. Eu tinha o meu quarto lá em cima, mas tinha o meu quarto ali embaixo. Quando eu cresci, eu gostava de passear de noite, né? Botava as crianças pra dormir e ia embora. E quando eu voltava, pra não acordar ninguém, eu dormia naquele quarto embaixo. Então, eu tinha dois quartos.

\section{Eles eram ricos, não?}

A minha patroa era muito society, né? Ela recebia muitas pessoas, principalmente poetas, declamadores. Tinha muitas festas. Eu me lembro que a gente fez uma festa de aniversário pra ela, e foi minha primeira experiência de fazer docinhos. Tinha uma cesta, cheia de rosas amarelas que ela gostava. Mas as rosas eram docinhos. E ela em cima e nós embaixo, e ela não desconfiou que a gente estava fazendo uma festa pra ela. E nós convidamos todos os amigos da época. Era muita gente. E de noite a gente disse pra ela: "A senhora, por favor, vê se a sra. põe uma roupa porque alguém vai chegar aqui". E quando ela chegou na sala, que a sala era um jardim, com todos os amigos ali. Ela ficou muito emocionada e falou “de quem foi essa ideia?”. Foi da mãe dela. A mãe dela era muito amiga, e o que a gente pedia ela realmente atendia. O pai não era muita coisa, não, mas também

7 A Juventude Operária Católica, movimento ligado à Igreja Católica, foi fundado em 1923, em Bruxelas, tendo se expandido internacionalmente sob a liderança do padre Joseph Cardjin. Mantinha seu caráter religioso, mas voltava-se, também, para os problemas da classe trabalhadora e da realidade social. Foi bastante influente no movimento sindical brasileiro entre os anos 1960 e 1980. 
deixava a gente fazer. Na minha opinião, eram ricos, porque eles tinham todos os empregados. Eu sei que eu não ganhava dinheiro [salário], a Totonha também acho que não, mas a copeira ganhava. E a lavadeira e a passadeira também. Porque eu sei que ninguém ia embora.

Esse tipo de arranjo, de trabalhar em troca de um lugar pra dormir...

Na minha época era comum. Aquelas empregadas vieram todas jovens. Era tudo assim. Ia lá na roça, dizia "ah, eu levo, deixo estudar e trabalhar”.

A relação da senhora com a aquela família...

Não era de empregada. Eu digo, tudo o que eu aprendi, eu aprendi lá. Eles tinham uma casa em Itacuruçá. Era uma casa linda. E eu ficava lá naquela casa; e eles tinham dois caseiros. Tinha um rapaz que ele era pra passear com a gente de barco. A gente fazia uma cesta de sanduíche, entrava no barco de manhã, rodava aquela restinga da Marambaia o dia inteiro com as crianças. Quando chegamos de volta, alguém perguntou assim pra ela: "Glorinha, o que você fez com essas crianças que tão o tição?” (risos). Ela dizia assim: "Pergunta pra essa maluca, que quando chega em Itacuruçá, ela não fica dentro de casa. Vai embora pro mar adentro". E era assim, minha vida foi assim, viu? Eu também fui muito para a Cidade do México. Eles tinham parentes lá. la pra lá, passeava, ficava quatro, cinco meses. Todas as férias das crianças, quando a gente não ia pra Itacuruçá, a gente ia pro México.

Só pra confirmar: a família dos seus patrões era branca?

Era.

E todos os vizinhos também?

Também.

E as empregadas?

Negras.

Todas?

A maioria era negra. A Totonha era velha e era negra. A lavadeira era negra. A menina do Ceará era da minha cor, mas não se considerava negra, não.

E as empregadas eram do Rio ou também tinha gente de outros lugares?

Tinha de outros lugares. Mas, mais próximas do estado do Rio mesmo. Tinha muita gente de Volta Redonda e Barra Mansa. Eu conheci essas cidades através de uma delas. Agora, a copeira era do Ceará.

E essa questão de ser negra, era algo que vocês conversavam ou não?

Não, naquela época não tinha essa história de se discutir cor...

Mas a senhora destacou que vocês todas eram negras e que os patrões eram brancos...

Não, isso a gente via a diferença, né? E uma outra diferença que tinha, era que a gente tinha uma mesa só. Não era empregado comer depois, não. Nessa casa da Tijuca, era uma mesa só. Hora de almoço, todo mundo sentado, acabou. Então, era uma espécie de família. 


\section{E senhora se considerava da família?}

Não, mas eu tinha uma certa liberdade. Se [iam] pro teatro, pro Municipal, pro Maison de France, pro Carlos Gomes, ia todo mundo, eu também ia. E sentava junto com eles. Então, não tinha diferença. A diferença era só a cor e o dinheiro que eu não tinha.

A senhora falou que a primeira casa era frequentada por artistas. Políticos também frequentavam a casa do sr. Roberto e da dona Glória?

Também.

\section{A família era pró ou contra Getúlio?}

Era dividida. Meu patrão era muito Getúlio. A minha patroa não era muito por causa dos pais. Eles eram lacerdistas doentes.

Ah, na Tijuca... (risos)

É, quando Getúlio morreu... eu estava indo pra escola, e então alguém gritou: "Volta, que o Getúlio se matou". Eu já tinha 22 anos. Aí eu voltei. Quando eu cheguei na casa, estava cheia de políticos, que eu não me recordo mais os nomes. Aquilo ali não me interessava muito, não; eu não era da política nessa época. Não era nem contra nem a favor.

\section{Mas a senhora já votava. Lembra-se em quem votou nesse período?}

Não, eu votava porque eu tinha que votar. E ainda tinha que ver uma coisa, tinha que ver em quem que eu votava, porque o patrão era de um e a patroa de outro. [De toda forma,] eu achava que ele (Getúlio) era bom pro povo. Então eu fiquei triste [quando ele morreu]. Falei assim "ah, pronto, agora como é que vai ficar esse país?". As minhas amigas comentavam: "Mas como é que pode? E agora? Ele é o pai dos pobres". Aí hoje, quando falam muito do Lula, eu lembro daquela época. "Ah, o Getúlio é o pai dos pobres" e eu dizia assim "não é, não, porque ele não me deu nada" (risos). Olha, ele já tinha instituído os salários, já tinha CLT, e eu não fazia parte desse contexto, não. Eu continuava sendo aquela menininha que ganhava as roupas, ganhava comida...

\section{Seus patrões nunca lhe davam dinheiro?}

Não. Me davam um dinheirinho no final do mês, mas não era o salário. Era uma "mesada".

\section{A senhora tinha uma atuação como católica, certo?}

Eu tinha, não, eu tenho... Eu me formei catequista e entrei na JOC na igreja de Santo Afonso, na Tijuca. Ali eu fiz todo o meu aprendizado. E fui pra lá pra escola da catequese. Me formei em catequista e cantava no coro. Ah, olha só, eu era uma empregada que tinha uma certa liberdade porque eu era corista, dava aula de religião lá no Salgueiro, dava aula na igreja. Eu tinha minha liberdade.

\section{Na época já tinha grupo de doméstica?}

Já tinha, mas não era grupo de doméstica pelas domésticas, era a Juventude Operária Católica que tinha uma linha de valorização do trabalho doméstico. Só que a gente não entendia muito bem aquelas histórias de valorização. Através da 
JOC, eu conheci outros grupos. A gente tinha contato com operários, com essas mulheres de fábrica, mas a gente não participava, não ia pra lá junto.

Bem, então finalmente a senhora decidiu sair da casa da d. Glória e do sr. Roberto.

Na casa tinha um grupo de profissionais completos, não precisava mais de babá e não precisava de uma governanta, porque a Totonha era a cozinheira e governanta. Aí eu falei pra d. Glória que eu não queria mais ficar, porque os meninos haviam crescido. Que negócio era esse de eu ir para o clube acompanhar os dois porque a mãe e o pai não queriam ir? Ela disse: "Ah, mas não vai". E eu: "Vou, vou, se a senhora não me arrumar um emprego, vou trabalhar de cozinheira em algum lugar”. [Ao que d. Glória respondeu:] “Ah, que maluquice é essa, trabalhar de cozinheira". [Então] ela disse assim: "Você pode ficar e dirigir a casa". Eu disse: "Com essa cozinheira que a sra. tem? Ela vai me jogar uma panela fervendo na minha cabeça, e eu não quero briga com a Totonha". [Aí] ela disse: "Tá bom, então vou te ajudar. Eu te ajudo a arrumar um emprego".

\section{Como foi isso?}

Ela negociou meu primeiro salário, e então eu fui trabalhar no Leblon. Depois desse carinho todo que eu tinha na casa [da dona Glória], eu fui pra uma casa onde eu era empregada mesmo. E nessa casa, eu comecei a ver a diferença entre patrão e empregada. [Quando] cheguei lá na casa, no Leblon, o que eu encontrei? A cozinheira e uma passagem no meu nome em cima da geladeira pra eu ir pegar o menino em Bariloche. Eu perguntei pra cozinheira: “Essa sua patroa é maluca?”. Ela disse, “por quê?’. Eu disse: “Por quê? Ela não me conhece. Como é que ela me deixa uma passagem e vai pra Israel? Como ela me deixa uma passagem aqui em cima da geladeira pra eu pegar uma criança?". [Ela respondeu] "Ah, a senhora que pensa que ela não conhece. Ela fez isso porque ela sabia que podia fazer isso". E lá fui eu pra Bariloche, dois dias depois. Encontrei o Daniel, o filho dos meus novos patrões, com uma família que era parente. Fiquei 45 dias em Bariloche com eles e voltamos ao Brasil. E eles ainda não tinham voltado, fomos pra Teresópolis. Eles tinham uma chácara em Teresópolis. E lá aconteceu uma coisa interessante. A mãe dessa senhora, que era parente deles e estava com o Daniel, tinha duas crianças, mas não tinha babá. Quando eu cheguei lá, a cozinheira da casa falou pra mim: "Você só pode fazer as coisas pro Daniel. Não tem autorização pra fazer mais nada pros outros". Eu falei pra ela: "Ah, isso pra mim não dá. Tem três crianças aqui. Eu vou fazer sanduíche pra um e não fazer pros outros? Ah, não!”. E a gente ia brincar e, olha só, eu já grande e eles bem pequenininhos, Daniel tinha 2 anos. E fomos brincar de chicotinho-queimado no quintal imenso que tinha lá em Teresópolis. A cozinheira disse pra mim: "Olha, não pode. Não pode porque tem uma avó e ela gosta de descansar nesse quarto, e vocês fazem barulho". Eu falei “Ah, ela vai vir brincar com a gente" (risos). E no final, foi isso que aconteceu. Ela disse que eu não deixava ela dormir e não podia brigar comigo, porque eu não era empregada da filha dela. E aí, pronto. Quando meus patrões voltaram de Israel, foi aquele desespero, porque as crianças não queriam entrar no carro se eu não entrasse, não queriam ir passear se eu não fosse. E assim [o tempo passou]. Eu fui pra Israel, fui pra Bélgica, pra Alemanha. Até o Daniel fazer 15 anos.

\section{Como foi se mudar pro Leblon?}

Foi assim: na Tijuca eu tinha tempo de estudar, tinha tempo de dar aula [como catequista], tempo de conversar... No Leblon, às vezes, eu não tinha tempo 
de ir no banheiro. Eu era babá só do Daniel, mas tudo, tudo era Daniel. Pai e mãe eu só via de manhã quando eles se levantavam. O Daniel eles viam no final de semana, porque quando eles saíam Daniel estava dormindo e quando eles chegavam eu já tinha posto pra dormir.

\section{Daniel tinha quantos anos quando a senhora chegou?}

Dois anos. E a gente foi vivendo, e começou aquela coisa - eles tinham sítio em Teresópolis, em Quebra Frascos. E a gente ia praquele sítio. Era o mesmo problema, porque o Daniel queria ir pra Escola Britânica. A gente ia pra lá, eu ia ensinar português pras crianças lá e nós ficávamos quase o dia todo naquela escola. Quando voltávamos, cadê os pais? Tinham ido não sei pra onde. Então, aquela criança, foi mais ou menos eu e ele, eu e ele. E a recomendação que eu tive quando cheguei na casa - o patrão não falava muito, não. Tanto que ele nunca me chamava pelo nome: ele dizia assim, "oi, moça”. E ele falou pra mim: "Você é católica, nós somos israelitas", não falou que eram judeus. [Ele disse:] "Eu já sei que você é catequista formada. Aqui perto tem uma escola e você pode continuar dando suas aulas, mas não pode ensinar nem uma palavra do Novo Testamento pra ele, mas do Antigo você pode falar tudo".

\section{Qual era o nome deles, seus novos patrões?}

\section{Simon Friedmann e Annelise Kikoler Friedmann. ${ }^{8}$}

\section{E eles faziam o quê da vida?}

Eram representantes de pedras semipreciosas aqui no Brasil. Tinham escritório na rua da Quitanda. Recebiam muita gente do exterior, [principalmente] outros representantes. [Lembro que] um dia um representante da Inglaterra perguntou o que eu fazia naquela casa, já que tudo era comigo. Eu agendava, eu olhava, eu fazia tudo - sendo babá, hein? A minha carteira [de trabalho] só tem uma assinatura, que é de lá. E com o cargo de governanta. Foi governanta porque, em 1973, quando veio a primeira lei da doméstica, ${ }^{9}$ eu já tinha 14 anos trabalhando lá. O meu patrão, quando veio a lei, me disse de manhã: "Moça, você viu a televisão ontem?" - porque lá eu tinha salário, tinha férias e tinha folgas. Então, ele disse: “Moça, você viu que as férias agora são 20 dias?”. Eu disse: “É, são 20 dias úteis. O senhor ouviu também isso? Então, no dia que tiver feriado eu vou ter 33 dias de folga. Férias". Ele falou: "É. Outra coisa, eu vou assinar sua carteira". Eu respondi: "Não, o senhor vai assinar cinco carteiras". Nessa casa do Leblon tinha cinco empregadas. Ele: "Como? Então você vai pro INAMPS' ${ }^{10}$ fazer os registros". Eu falei, "vou”. Eu era meio babá e governanta, porque fazia as coisas da casa, né? Lá tinha empregada antiga, mas eu já entrei meio com esse status de babá e governanta. Eu fui pro INAMPS, registrei as cinco, e no final do mês ele me dava o dinheiro pra eu ir ao banco pagar os INAMPS de todas nós. Eu ainda não estava engajada na luta das domésticas. Eu tinha só um grupinho de babás.

8 A grafia dos nomes está transcrita como entendido na entrevista de Nair.

9 Lei n. ${ }^{\circ}$ 5.859, de 1972, que abre o direito à carteira assinada e à Previdência Social para as trabalhadoras domésticas.

10 O Instituto de Assistência Médica da Previdência Social (INAMPS) era o órgão governamental de saúde pública anterior à criação do SUS, responsável pela assistência médica a trabalhadores que contribuíam para a Previdência Social. Foi extinto em 1993. Nair provavelmente está se confundindo com os nomes, já que o INAMPS foi criado em 1977, data posterior aos eventos por ela narrados. 
A senhora fez um grupo de babás?

Nós fizemos, porque ali tinha um parquinho. Então tinha aquele mundo de babás ali e a gente começou a conversar. Tinha a Conceição, a Maria da Glória, a Lourdes, a Jéssica, a Anita, a Ester. Todas formavam aquele grupo. Eu e Lourdes éramos as únicas negras do grupo, o resto era tudo branquinha, mas a gente se dava bem. Eram mineiras, do Espírito Santo, da Bahia e uma de Pernambuco. E eu do Maranhão. Era um grupo de amigas. A gente ia pro cinema...

\section{E vocês conversavam sobre as patroas?}

Ah, aquelas que as patroas eram boas a gente falava bem; se eram más, falava mal. Se pagava pouco, a gente falava; se pagava bem, se dava as coisas, a gente falava [bem]. Eu viajava e ganhava muitos presentes, quando chegava elas comentavam: "Ah, pois é, você é rica, porque você vai...”. E eu: “Ah, não sou rica nada”.

\section{Essa foi sua primeira experiência com um grupo de domésticas?}

Não, na Tijuca tinha esse grupo da JOC. Na maioria, eram todas empregadas domésticas. [Havia também] os professores, aquelas assistentes sociais que chegavam pra conversar com a gente, as operárias, as irmãs de caridade, e era isso. Mas na maioria eram [domésticas].

Era uma possibilidade deixar de ser doméstica e virar operária?

Era, e eu não queria. [Muitas] faziam isso e diziam pra mim: "Que besteira, você vai ficar aí sendo escrava de patrão?”. Eu ouvi muito isso. Mas eu tinha também o problema de moradia. Eu tinha umas amigas, que uma... eu ia pra casa de uma delas quando eu estava de folga, e minhas folgas eram de 15 em 15 dias.

A senhora lembra da política dessa época, perto do golpe de 1964, do que estava acontecendo? Porque a cidade estava pegando fogo, não?

Em polvorosa... [mas] eu não estava nem aí.

A senhora votava em quem?

Ah, eu votava na esquerda mesmo. Eu não votava na UDN.

E a senhora lembra de algo especial daquela época?

Eu estava em Brasília, lá na inauguração com Juscelino.

A senhora foi na inauguração de Brasília!?!?

Fui. A babá dos netos do Juscelino era minha amiga. Era a Ester, do grupo de babás que a gente tinha. No dia da minha folga de semana, eu ia pra lá, no apartamento da família na rua Sá Ferreira, em Copacabana, pra eles saírem, a babá ter uma folguinha e eu ficava com as crianças deles. Então, o que eles fizeram? Quando foi inaugurar Brasília, eles disseram assim: “Ah, Bá, não dá pra você tirar uma folguinha do seu trabalho e ir com a gente pra Brasília, não?”. Aí eu [dei um jeito], que eu não sei ainda até hoje qual foi, mas arranjei dez dias de folga e fui pra Brasília.

A senhora não conversava sobre política com as amigas no grupo de domésticas?

A gente conversava. Tinha umas bem brigonas, que diziam assim: "Se eu pudesse eu matava fulano, se eu pudesse enfiava uma faca”. E eu falava: "Que 
negócio é esse? Você quer ser assassina por conta de quê?”. E a gente via as coisas que a gente não podia comentar. A gente só podia ouvir, ver e calar. E fazer igual aos macaquinhos, né?".

E a vida social da senhora?

Quinta-feira era dia de namorar. Aí eu ia namorar o marinheiro... Marinheiro chato.

\section{Como que a senhora o conheceu?}

Foi numa festa, como era mesmo que chamava? Um baile, uma gafieira. Eu gostava de dançar, e nessa gafieira eu conheci o sujeito. A gente começou a namorar, e eu falei: "Só tenho livre quinta-feira". E aí namoramos, sabe quantos anos? Dez!

\section{Qual era o nome dele?}

José Vasconcellos. Mas não é o Vasconcellos da televisão, não (risos).

\section{Ele era negro ou branco?}

Negro. E o que aconteceu: [Ele disse:] “Vamos fazer nossa casa?”. [E eu respondi:] "Vamos". Montamos um apartamento lindo ali na rua do Riachuelo. Quando tinha tempo, eu ia arrumar meu apartamento, pensando "vou casar e vou morar aqui". Faltavam 23 dias pra eu me casar, [e os meus patrões propuseram:] "Vamos pra França, você vai com a gente pra França". E eu: "Não vou, vou casar, como eu vou com vocês pra França?". Aí eu estava descendo a [rua] Visconde de Pirajá, e vem uma mulher com uma criancinha. Ou seja, ela me conhecia, eu não conhecia ela. Ela: “Ei, peraí”. Eu falei: “Quê que é?”. [E ela:] “Tá vendo esse bebê aqui? É do seu futuro marido. No dia do seu casamento, eu vou matar ele lá na igreja, porque ele quer a criança pra você criar, mas não me quer". Falei: "Ah, é? Tá bom. Hoje é dia da gente se encontrar, então acabou: eu vou pra França”. Voltei, fui pensando: "Não quero mais". Cheguei em casa falei pra dona Annelise: "Pode comprar minha passagem, eu vou pra França”. Fui de noite, cheguei lá na [rua] Visconde de Albuquerque e disse: "Olha, só vim dizer pra você que essa aliança aí é tua, não quero mais". [Ele]: "Ah, quê que foi? Ficou maluca? Aquele apartamento que a gente construiu?". [E eu]: "Não quero mais. Você arrumou filho com outra mulher, então vai casar com ela, não comigo. Não tem casamento”. Peguei a aliança joguei lá dentro do canal da Visconde de Albuquerque. Ele ficou louco, e reclamou, gritou. Falei: “Acabou!". Quatro dias depois fui pra França. Quando voltei tinha um bolo de cartas, telegramas. Peguei aquilo tudo e fiz uma fogueira (risos). Ah, sofri muito, mas o sofrimento passou. Um dia encontrei ele com a criança na praia. Aquilo ali foi o início de uma perseguição, porque toda vez que eu saía, eu encontrava ele. "Ah, porque eu preciso falar com você...”, [ele] falava. "Não vou". Eu custei, mas depois não sei pra onde ele foi. Graças a Deus, sumiu. E não namorei mais.

Nos conte como a senhora se aproximou da Associação das Empregadas Domésticas.

Em 1969, já morávamos em Copacabana, e eu costumava descer com o Daniel na avenida Copacabana, ${ }^{11}$ na parte da manhã. Numa dessas caminhadas, eu vi um papel escrito na Biblioteca de Copacabana: "Minha patroa é a mais bonita".

11 Atual avenida Nossa Senhora de Copacabana. 
Falei: "Ué, que história é essa?", e vi que era um programa do Flávio Cavalcanti" na televisão, elegendo as patroas mais bonitas, junto com a Associação de Empregadas Domésticas do Rio de Janeiro. Eu não conhecia, falei “vou lá descobrir o quê que é isso". De noite, coloquei o Daniel pra dormir e avisei minha patroa que estava indo. Ela disse: "Você já vai se meter com essas mulheres doidas?". Falei: "Eu também sou uma doida. Vou lá". A biblioteca era na rua Miguel Lemos. Entrei e perguntei: "Quê que é isso aqui?”. “Ah, somos da Associação Profissional de Empregadas Domésticas". Tinha uma delas, Maria da Hora, que já não era mais doméstica, mas estava ali assessorando as meninas, e a Odete Azevedo Soares, que era assistente social e [que brigaria] comigo mais tarde. A Odete Conceição, que era a fundadora da organização de domésticas do Rio de Janeiro, e a [então] presidente, que era Expedita não sei das quantas. Eu comecei a ir. Toda folga que eu tinha, eu ia pra lá. Alugaram uma quitinete na rua Ipiranga, em Laranjeiras. As domésticas que não tinham família aqui no Rio podiam ficar lá durante o final de semana. Falei: “Opa, tá bom pra mim”. Eu fui pra lá, e quando cheguei comecei a conversar. A Odete falou que tinha feito uma carta pro presidente Médici, pra ver se [ele] dava alguma coisa pras domésticas. As domésticas não tinham horário, não tinham carteira de trabalho, era só trabalhar e não tinham nada. Em dezembro de 1972, veio a resposta. Ele não respondeu o que ela perguntou, mas deu a Lei n. ${ }^{\circ}$ 5.859, a primeira das domésticas. Essa lei dava direito a carteira assinada, férias de 20 dias, direito de pagar a Previdência Social, e estava bom, todos ficaram felizes na época. Passou a vigorar a partir de 1973. Em 1973, me convidaram para entrar na direção. Falei: "Tá bom, eu vou entrar na direção”. [Então elas disseram:] "Não, mas você vai ter que ser a presidenta".

Como foi a primeira reação dos seus patrões em relação a sua aproximação com a associação?

Um dia, eu dei uma entrevista - aí eu já tinha conhecido a associação. E ela [d. Annelise], quando leu a entrevista, ficou muito zangada. Ela quando ficava zangada não falava com a gente, não. Eu passava, olhava [e perguntei:] "O que aconteceu?". [Ela disse:] "Eu li aqui, você fez um rosário aí de coisas e não falou que faz parte da família". Eu falei: “Como é que é?". Ela: “É, porque você é da família”. Eu falei: “Da família? Da família é o Daniel. Eu tenho salário, eu tenho férias, eu tenho horário pra entrar e sair aqui da sua casa, eu tenho folga de $15 \mathrm{em}$ 15 dias. O Daniel entra aqui 2 horas da manhã, traz não sei quem - ele é da família. $E$ além de tudo, eu sou negra. A senhora é alemã e branca. Eu não sou branca. Então, eu estou numa casa, que eu estou há muito tempo, que eu gosto de estar aqui, apesar de algumas coisas, mas eu não faço parte dessa família. A minha família é aquela das minhas colegas lá do subúrbio, aquela família que não é a biológica, que eu adotei lá em Nova Iguaçu. Essa é a minha família, são negros como eu. E que, no final do ano, quando a senhora viaja e eu não viajo, eu posso trazê-los e deixá-los aqui, mas eu tenho que pedir autorização para a senhora. O Daniel não precisa fazer isso. Eu preciso".

\section{O que Ihe atraiu na associação? Por que resolveu ficar?}

[Cheguei quando elas] estavam mudando para a rua Ipiranga, o que me interessou, porque eu podia ficar lá sábado e domingo com outras domésticas

12 Flávio Cavalcanti foi um jornalista responsável por diversos programas de rádio e TV de sucesso no Brasil, principalmente entre as décadas de 1960 e 1970, tendo trabalhando na TV Tupi, Rede Bandeirantes e no jornal A Manhã. 
que não tinham casa no Rio de Janeiro. Só que quando eu cheguei lá, eu comecei a conversar com as colegas que estavam muito insatisfeitas, comecei a falar sobre os direitos que não tínhamos e o pessoal me convidou logo para a direção e para encabeçar uma chapa. Eu sei que formou a chapa, e lá fui eu. Ganhei. 1973.

\section{Por que a senhora topou participar da chapa?}

Pra dizer a verdade, eu entrei sem saber muito bem o que eu ia fazer ali, só sabia que ia ser presidente. Falei: “Opa, olha lá”. Status, né?

\section{A senhora sabe qual era a história da associação? Como surgiu?}

Em 1961, a Odete Conceição trabalhava na rua Leopoldo Miguez. Trabalhava em um prédio com cinco andares. O último andar era o apartamento dela, um terraço que tinha um quarto. Ali ela fazia bailes, fazia reuniões da JOC, reunia as domésticas. E o que [a] levou a fundar uma associação? Ela disse que saiu uma vez de uma reunião da igreja, quase onze horas da noite, e encontrou uma empregada com a mala, na porta da igreja, sem saber pra onde ir porque a patroa tinha-lhe posto na rua. Ela disse: “Ah, não pode, vamos dar um jeito". E com a Maria da Penha, com a outra Conceição Caetano e umas outras que eu não recordo mais o nome, elas se reuniram pra criar um grupo de empregadas domésticas. A Odete Azevedo, como era assistente social, começou a orientá-las e elas fundaram a associação.

A senhora foi eleita em plena ditadura militar...

Sim, horrível. Mas a doméstica era a única que não era incomodada na ditadura nesse ponto, porque eu tive colegas que foram presas. Mas eu podia fazer as reuniões. Eu tinha um fusquinha velho que me levou a muitos lugares para fazer as reuniões. Quando eu fui eleita presidente, no mês seguinte tinha um congresso de domésticas aqui no Rio de Janeiro, no Colégio Assunção, lá em Santa Teresa. Vieram domésticas do Brasil inteiro. E o Jornal do Brasil foi cobrir o trabalho lá. O pessoal colando nas minhas costas para eu não dar entrevistas. Primeiro, porque eu estava chegando naquele momento, e depois, porque eu não sabia muito a história do trabalho doméstico. Eu sabia que ele era oriundo da escravidão, sabia que a JOC lutava pela emancipação, mas não sabia por que aquela demanda. Então, uma irmã de caridade de Niterói e a Odete Azevedo não me deixaram dar entrevista. E o Jornal do Brasil queria a entrevista da presidente. Então, não fizeram nenhuma [entrevista]. Na segunda-feira, fizeram um artigo [chamado] "Congresso de Clausura", porque a presidente não podia abrir a boca. E aí sim, entrei na luta. Eu digo para as meninas que quando eu descobri que aquela Lei de 1973, que dava direito a carteira assinada, tinha que ter um salário mínimo escrito na carteira, mas o FGTS era facultativo, o patrão pagava se quisesse. Então, eu comecei a conversar com as pessoas: "Nós queremos os direitos, mas que direitos são esses que não nos dão completos? A gente tem carteira assinada, e o patrão tem direito de não pagar um salário que está escrito na carteira. Vocês acham que isso é bom? Vocês vão chegar a algum lugar? Porque, como eu aprendi que palavras o vento leva, que só vale o que está escrito, então vale o que está escrito. Se você escreveu que quer sua carteira assinada e você se sujeita a não ganhar salário, então você tem que pensar". E a gente começou a brigar para que a lei mudasse. 
Em algum momento a senhora teve a percepção que a polícia ou o DOPS podiam estar de olho em vocês?

Quando eles me levavam escondida naquelas reuniões, eu achava que era por causa da polícia.

Quem Ihe levava?

O Leônidas, da Caritas, ${ }^{13}$ José Fortunato, Zé Ramos e João Fernandes. Eles eram operários da JOC, da construção civil e dos outros sindicatos. Levavam a gente pra fazer reuniões em lugares que eu não sei onde é até hoje. Eu estou me lembrando só dos [trabalhadores] da construção civil, dos metalúrgicos, e qual era o outro, gente? Esses dois estavam muito presentes, porque eles estavam muito ali conosco. [Chegavam até a gente] através do Tibor Sulik, que era um assessor da Diocese do Rio de Janeiro e trabalhou muito na JOC. Ele morava na Ilha do Governador e nos ajudava muito nisso.

Além da JOC, havia outras organizações de esquerda que procuravam se aproximar de vocês?

Patroas! Tinham algumas patroas que se diziam feministas. Essas patroas feministas chegavam até a gente, sim. Até que um dia, eu disse... deixa eu ver se me lembro da minha palavra... ela dizia que lutava pela emancipação da mulher, e eu disse pra ela que, enquanto uma mulher, para se ver livre lá fora, tinha que deixar outra mulher fazendo o que ela devia fazer, eu não via jeito de libertação. Por que, como é possível? Eu quero ser livre, mas atrás de mim tem que ficar uma pra ser escrava? Então, eu não via libertação nisso.

Por que a senhora acha que o Médici fez essa lei para as domésticas?

Até hoje ninguém entende, porque não foi isso que a menina pediu pra ele. A Odete Azevedo e Odete Conceição escreveram uma carta pedindo que não escravizassem tanto as domésticas - na época eram chamadas de empregadas. $E$ elas escreveram pedindo que desse um jeito. Ele não respondeu e editou essa lei. Não foi uma coisa discutida, não foi discutida conosco, não perguntou "é isso que vocês querem?". Jogou a lei.

Vocês sofreram algum tipo de perseguição do governo militar?

Não, aqui no Rio, não. Em Pernambuco, minha colega foi presa três dias, a Lenira. ${ }^{14}$ Porque eles procuravam armas - ela fez um livro "Só quem vive é quem sabe" -, eles procuraram na casa da patroa dela, embaixo da cama dela. Não acharam, mas ela ficou três dias presa.

E algum outro tipo de contato? Tipo: "Demos a lei e agora vocês devem isso pra gente".

Não, não teve isso aqui no Rio. Eu não me lembro. Em nenhum momento chegou ninguém do governo ou do Médici para falar alguma coisa. Nada vezes nada. E olha que eu fiquei nessa presidência entre 1973 e 1979. Em 1979, eu fui

13 A Cáritas Brasileira, fundada em 1956, é ligada à CNBB - Conferência Nacional dos Bispos do Brasil - e atua na promoção dos direitos humanos. Faz parte da rede Cáritas Internacional e atua majoritariamente através de voluntários.

14 Lenira Carvalho, participante da JOC, foi fundadora da Associação de Trabalhadoras Domésticas do Recife em 1979 e é sindicalista ainda em atividade. Além do livro mencionado por Nair, uma série de entrevistas sobre sua trajetória de vida e luta foi organizada no livro "A luta que me fez crescer”, publicado em 1999. 
para vice-presidência, fiquei até 1982. Em 1982, continuei na vice-presidência até 1986, quando voltei a ser presidente. Em 1988, a associação se transformou em sindicato, e eu fui a última presidenta como associação. Um ano para fazer preparação. Fui a primeira presidente. Foi o ano que eu mais trabalhei, de 1987 até 1988, período da Constituinte. 1988 também foi o ano em que fundamos a Confederação Latino-Americana e do Caribe de Empregadas Domésticas. [O Brasil sediou] o $3^{\circ}$ Congresso da Confederação, e na $4^{a}$ conferência, que aconteceu em 1996, na China, eu fui representar a América Latina.

Em 1973, a senhora não tinha muita experiência, mas, apesar disso, foi escolhida para ser presidente. Por que acha que isso aconteceu?

Acho que era porque eu falava muito.

\section{Por causa da sua personalidade?}

É, acho que porque eu reclamava muito, então eles acharam que eu ia resolver o problema, e eu não resolvi.

A senhora achaque tinha a ver com o fato de ter tido uma experiência como empregada doméstica mais atípica? No sentido de ter contato com o mundo, portanto alguém que parecia mais preparada?

Eu não sei o que eles acharam, porque ali tinha gente [preparada]. A Maria da Hora, por exemplo, era uma menina que estava terminando o científico, trabalhou na Cáritas, Banco da Providência; tinha a Terezinha, tinha outras lá.

Quando a gente não tem muita experiência com política sempre tem alguém que vem tentar dizer o que a gente tem que fazer. Quem é que fazia isso com a senhora nessa época?

Era a Heloneida Studart e a Isabel Picaluga, que morreu, mas pra mim foi uma professora. A Ângela Borba [também]. Feministas. Essas foram as minhas professoras fora do trabalho doméstico. ${ }^{15}$

\section{E o que elas Ihe ensinaram?}

Elas diziam para mim: "Olha, patroa só quer o seu trabalho, cuidado. Mas cuidado também com certos colegas - fulana está ali de olho no seu cargo. E você tem que ser firme, você nunca pode voltar atrás, então pense bem no que você vai dizer, porque vai ficar escrito".

Isso já na primeira gestão?

Não, na primeira gestão, eu não tinha ninguém. E eu fui eleita lá na rua Ceará, onde a gente alugou uma casa linda na rua dos Araújos. ${ }^{16} \mathrm{~A}$ gente fazia festas, forrós... mas forrós a gente já fazia na rua Ceará, na praça da Bandeira, todo domingo. Tinha umas meninas que tinham uns namorados, né? Muitos eram nordestinos.

15 Nair faz referência a Heloneida Studart (1932-2007), escritora e jornalista cearense, seis vezes eleita deputada estadual pelo PT do Rio de Janeiro; Isabel Fontenelle Picaluga (1932-1992), ex-presidenta da Associação dos Sociólogos do Brasil e militante do PT; e Ângela Borba (1953-1998), ativista feminista do Movimento Brasil Mulher e uma das fundadoras do PT no Rio de Janeiro.

16 A frase, com a referência a duas ruas diferentes, está transcrita como foi dita na entrevista. 
Havia muitas festas...

Nessa época a gente ia pra Quinta da Boa Vista, porque tinha umas quermesses da prefeitura; e eles eram nossas mulas, porque carregavam nossas panelas de canjica, de sopa, feijão tropeiro, e vendíamos tudo na Quinta da Boa Vista.

\section{Para arrecadar fundos para a associação?}

Para a associação. E porque a gente tinha um grupo de colegas que a gente tinha que dar uma ajuda de custo pelo trabalho delas, porque não eram daqui, não moravam aqui.

Se eu entendi bem, a senhora organizou sua primeira gestão muito a partir da luta pelos direitos concedidos com a lei no governo Médici. Como era isso no dia a dia, como a senhora convencia as empregadas?

A gente tinha reunião dominical e a gente enchia muito a associação.

Mas como convenciam as empregadas?

A gente tinha panfletos, [tipo] aquele panfleto que eu conheci na rua? A gente fazia também.

Mas muitas não eram analfabetas?

Mas provavelmente davam jeito de alguém ler para elas, porque chegavam.

Mas quem fazia, quem imprimia esses panfletos?

A gente tinha alguns amigos de gráfica.

\section{A JOC ajudava?}

Ajudava e esses amigos imprimiam. Na Diocese do Rio de Janeiro, era a época do dom Helder Câmara ${ }^{17}$ e ele era muito amigo das empregadas domésticas. Ele abria o máximo que ele podia a igreja. Tanto que existia a Pastoral das Domésticas, eu fui uma das coordenadoras.

\section{E como eram as reuniões?}

Nessas reuniões, todo mundo gritava, falava, reclamava, e a gente orientava. E tinha a secretária, que era muito eficiente e mais instruída do que eu, e ela pontuava tudo ponto a ponto.

\section{A associação tinha algum advogado?}

Tinha, nós tínhamos advogados voluntários. Mas as festas que a gente fazia, [a gente] dava um percentual para os advogados, mas não era um salário fixo. Era uma ajuda de custo, mas que a gente não deixava de dar.

\section{E que tipo de reclamação aparecia mais?}

Dos salários que não eram pagos, férias e folgas que não eram respeitadas. Isso era do que mais se reclamava. Ah! E ainda tinha o problema das meninas menores, que trabalhavam nessas casas, vindas do interior com a promessa de estudar, e chegavam, e só trabalhavam. Nós tínhamos muitas reclamações sobre isso e pedíamos ajuda das pessoas para chegar nessas coisas.

17 Nair se equivoca com as datas aqui, já que dom Helder atuou no Rio de Janeiro até 1964. 


\section{E naquela época já tinha reclamação sobre assédio?}

Ah, isso sempre teve! Patrão passando a mão na empregada, os convidados, os filhos querendo ser iniciados na vida sexual com as empregadas. Isso sempre teve.

Mas elas tinham coragem de falar? Nas reuniões isso aparecia?

Na reunião, se não tivesse homem, elas se abriam e contavam as histórias. Se tivesse homens, você não conseguia ouvir nada. Nessas reuniões mais fechadas, as pessoas realmente se abriam mais, porque quando era grupão não dava para falar muito, não.

\section{E vocês conseguiam fazer alguma coisa?}

Aí, não! Infelizmente não tinha como fazer nada. Eu acho que ainda hoje não tem. Mas hoje a gente já pode fazer denúncias, naquela época não podia.

\section{Mas isso aparecia muito?}

Mas muito mesmo. E ainda tinha aquela história da patroa dizer: "Ah, mas ela deu confiança!”. Eu usava roupas curtinhas e a minha patroa às vezes [dizia] para mim: "Ó, acho melhor você botar umas roupas mais compridas porque seu Fulano está de olho em você". Eu: "Deixa ele ficar de olho, deixa ele olhar". Mas acontece e aconteceram muito essas coisas.

Logo no início, vocês já entenderam que precisavam ter reuniões mais fechadas, só com mulheres?

Não, [no início, eram reuniões abertas para discutir] salário e férias. Com o caminhar dos anos, fomos conhecendo outras pessoas, de outros sindicatos, essas mulheres feministas, um grupo de patroas que queriam ser boazinhas e iam lá orientar a gente - orientar à moda delas, mas iam. Aí a gente começou a ver que isso não podia ser assim, essa legislação tinha que mudar.

A primeira gestão da senhora foi em plena ditadura. As pessoas não tinham medo de ir para as reuniões?

Não. Não tinham. E por que não tinham? A gente achava que eles não iam mexer com as domésticas, porque se veio uma legislação em plena ditadura militar, a gente achava que estava livre. Nós nos reuníamos, nós fazíamos caminhada. Essa praia de Botafogo, a gente vinha fazendo caminhada lá da rua Ipiranga. Vinha, e ninguém chegava perto da gente para dizer "não pode". E eu dizia assim: "Por que o Leônidas [da Cáritas] escondia tanto a gente, se ninguém vem perto da gente brigar nem falar nada? Ou eles acham a gente tão analfabeta assim? Ou tão tapadas que não vamos fazer nada?".

A questão racial já começava a aparecer nesse momento? Aparecia a questão de haver uma maioria de domésticas negras?

Não aparecia. Agora sim! Agora aparece. Mas, naquela época, 1973 até 1979, não aparecia. Ninguém olhava para sua pele.

Ou se olhava, não falavam...

Isso! [Mas] não era um assunto de reunião. 
Mas era um assunto entre vocês? suja".

A gente as vezes falava: "Ah, olham a gente assim, como se a gente estivesse

\section{Elas contavam experiências de preconceito racial?}

[Sim], mas não diziam que era preconceito racial, não, diziam só que: "Ah, tá com inveja do meu trabalho" ou "Ah, eu faço melhor"...

\section{Então não aparecia como uma questão?}

Não [da mesma forma] que hoje a gente discute, né? É como eu digo para todo mundo: Olha, eu gosto de discutir mesmo, porque quanto mais eu discuto a minha negritude, mais as pessoas dizem que a racista sou eu, não são elas. Então, eu deixo as coisas caminharem. Eu vivi muito - só lá nos EUA me disseram que eu não era negra nem era branca, que eu era desbotada. Eu disse assim: "Essa cor ainda não existe na minha terra. Existe pardo". Mas eu não me considero parda, eu me considero negra. Olha meu cabelo!

\section{Além das reuniões, que outras formas de mobilização vocês faziam?}

Também na igreja. A gente ia e lá falava com todas as meninas que a gente achava que trabalhavam em casa de família. Eu [também] lembro que uma vez, eu e a Zica, lá da Zona Oeste, colocamos 500 domésticas, em uma quinta-feira, 17 horas na praça Serzedelo Correia. Você não via nada [mais]; só se via as meninas. Começou a chegar a imprensa, curiosa, porque alguém deve ter telefonado, e perguntou o que nós estávamos fazendo ali. Era época em que nós estávamos nos mobilizando para a Constituição. Acho que em 1987.

\section{A senhora lembra quantas associadas vocês tinham na primeira gestão?}

Tínhamos muitas. Eu lembro que no primeiro ano, 1973, a gente associou mais de mil colegas. De abril até dezembro.

\section{Por causa da lei?}

Por causa da lei. Ela foi editada em dezembro de 1972, mas só foi promulgada no dia 8 de abril de 1973. Depois teve uma pausa, com a história de que com a assinatura na carteira a patroa não precisava pagar o salário integral, pagava o que quisesse. Aí a gente começou a ir para esses congressos, fazíamos congresso de doméstica. No de 1974, a gente foi para Belo Horizonte. O Arnaldo Pietro, ${ }^{18}$ ministro do Trabalho, foi com o braço quebrado e foi a primeira vez que a gente teve um convite para ir a Brasília como representante de categoria. Fui eu do Rio de Janeiro, uma colega do Espírito Santo, de Minas Gerais e uma de Brasília; fomos quatro. E aí fomos de avião, hotel, carro com motorista.

Tinha alguma região da cidade em que vocês eram mais organizadas?

Eu acho que era Tijuca.

\section{Mais que a Zona Sul?}

Muito mais! Zona Sul era difícil, porque todo mundo lá no final de semana

18 Em 1974 o deputado federal gaúcho, Arnaldo da Costa Prieto, assumiu como ministro do Trabalho e da Previdência Social do governo de Ernesto Geisel, tendo a pasta se desmembrado em duas logo após sua indicação. Continuou como ministro do Trabalho até 1979. 
ia para casa. Tijuca, não. Lá tinha muita gente que vinha de Madureira, de Campo Grande. A gente tinha muita gente.

E muitas das associadas moravam em favelas?

Não, não moravam muito em favela, não. Moravam mais para a Zona Oeste.

\section{E na Baixada?}

A Baixada, como sempre, já naquela época tinha muita gente. Tanto que a gente aqui do Rio começou a ajudar as meninas lá em Nova Iguaçu a formarem uma Associação de Empregadas Domésticas. Isso nos anos 1980, 1982, por aí. Quando chegou em 1988, elas fundaram o sindicato delas antes do Rio de Janeiro.

Lá nos anos 1970, como vocês resolviam quando as pessoas iam reclamar de salário e férias?

A gente dizia "você tem que conversar com a sua patroa", porque nós não tínhamos como chegar nos patrões. Nós éramos meio isolados....

\section{E como não tinha negociação coletiva...}

Continua não tendo negociação coletiva, mas hoje a gente pode falar com patrão de frente, discutir e dizer "isso não está certo".

Mas naquela época não?

Não!

Então vocês recomendavam os associados a conversar?

A conversar. E os patrões que chegavam lá iam para nos ajudar financeiramente. Tinha um grupo de patrões que ajudava. [Diziam:] "Tá faltando o quê? Tem lanche para vocês?".

Mas eles faziam isso por quê? Eram pessoas progressistas, de esquerda?

Diziam que eram, né?

Havia outros auxílios nos anos 1970?

Sim, a Denise, da Bélgica, era professora e ela angariava um dólar por semana entre as empregadas domésticas lá na Bélgica e nos enviava o dinheiro através da Odete Azevedo Soares, que era amiga dela. Não sei a história, mas sei que era assim. E ela vinha de três em três anos ao Brasil e se reunia conosco.

Vocês orientavam as empregadas a conversar com os patrões. Se os patrões se recusassem a conversar, o que vocês faziam?

Não podíamos fazer nada, infelizmente. Mas a gente continuava dizendo "tem que bater na tecla, tem que continuar conversando".

A senhora foi presidente da associação de 1973 a 1979...

Sim, e depois fui vice, vice de novo e presidente de 1984 a 1993. 
No início dos anos 1980, a CUT e o PT foram criados. Vocês se envolveram nesse movimento?

Eu, Josefa, Prazeres, a gente caminhou junto com Lula lá em São Bernardo do Campo na criação do PT. Tinha o Jacó Bittar, ${ }^{19}$ tinha muita gente...

\section{Mas como é que vocês chegaram até lá?}

A Benedita da Silva ${ }^{20}$ acompanha os direitos das domésticas desde que ela era vereadora aqui no Rio de Janeiro. Ela sempre esteve junto da associação e depois do sindicato. Então, a gente era indicada para ajudar. E, nessas indicações, fomos para São Bernardo. Andamos muito lá.

\section{Mas o grupo de domésticas participou da criação da CUT?}

Da criação da CUT, não. Da criação da CUT fui eu, a Eloisa [e] a Ana Cleta, que já morreu. Tinha uma rejeição grande - dessas patroas burguesas que tinha -, e as meninas não queriam entrar de jeito nenhum. Mas eu fui. Na época eu era presidenta. E a Maria dos Prazeres, que está em Pernambuco hoje, foi uma grande opositora. Trabalhou muito no sindicato, mas foi uma grande opositora. No final, a gente conseguiu criar o PT, a CUT e filiar o sindicato na CUT. Eu fui diretora da CUT na segunda gestão, já.

\section{Enquanto representante das domésticas?}

Enquanto representante da categoria [da CUT] do Rio de Janeiro.

\section{Então, nesse momento você já estava bem mais interessada por política?}

É, aí eu já participava, ia para as reuniões políticas mesmo. A gente se reunia, não só com a CUT, mas com o PDT, o partido do Brizola. Também tive muito contato com ele. Na época das Diretas Já, [a gente ia para os comícios com] Heloneida Studart, Ângela Borba, Isabel Picaluga, Moema Toscano, Fani Taba e outras. A gente lutou, todo mundo junto.

\section{E na época da Constituinte...}

Nessa época eu [ainda] trabalhava, o Daniel já era grande. Eu já estava viajando muito, então eu precisava ir para Brasília. Um dia eu sentei e disse para a minha patroa: "Olha, eu abdico das minhas férias, mas a hora que eu precisar viajar, estou indo". Um dia, ela disse assim "você nunca pergunta se pode, você diz 'eu vou". Eu respondi assim "ué, o que a gente combinou? Eu também nunca digo para senhora 'ah, já faz um ano, eu queria tirar férias"”. Porque aí eu comecei a ter convites para viajar para o exterior. E eu ia para o exterior e ia para Brasília. $\mathrm{Na}$ época da Constituinte, nós ficamos em Brasília, e tem uma reportagem que estamos eu, Josefa, Creusa, uma menina do Paraná - quando nós enchemos aquela esplanada; os jornais não disseram uma palavra.

19 Petroleiro, político e sindicalista brasileiro, um dos fundadores do PT e da CUT. Em 1988, foi eleito prefeito de Campinas (SP).

20 Benedita da Silva foi trabalhadora doméstica, líder comunitária e a primeira mulher negra a ser eleita vereadora no Rio de Janeiro em 1982. Em 2002, com a renúncia de Anthony Garotinho, assumiu como governadora do estado. Atualmente é deputada federal pelo PT (RJ). 
Com quem vocês iam? Quem dava a possibilidade de ir até Brasília fazer as demandas?

A Jaqueline Pitanguy, o doutor Ivo Pitanguy, ${ }^{21}$ que também já morreu, e a Leila Linhares, que é uma advogada feminista muito boa. Junto com a Benedita da Silva, a Maria de Lourdes Abadia, ${ }^{22}$ que não era da esquerda, e a Jandira Feghali; ${ }^{23}$ eles proporcionavam todas as nossas idas. Primeiro, a gente ia para Brasília de ônibus, de van, que quebrava no meio do caminho. Dormíamos em uns papelões, porque não tinha lugar. Depois, com o passar do tempo, íamos para a casa da Bené [Benedita], o Paulo Banana arranjava uns hotéis, umas pousadas de 15 reais. Toda semana a gente estava em Brasília. Eu ficava irada quando entrávamos naquele plenário e estava o Almir Gabriel, ${ }^{24}$ que já se foi, e ia votando; e quando chegava na pauta das domésticas, ele invertia. Tanto que, no dia que foi votado os direitos das domésticas, em 1988, nós tínhamos saído às 15:45h do plenário, e a Bené com as outras pessoas que eu citei fizeram vaquinha para nós voltarmos; e quando voltamos, no dia seguinte, quando encontrei as portas abertas, perguntei: "Ué, cadê os jamantas?" - porque eu chamava os seguranças de jamantas. Chegamos no PT, tinha uma menina meio dormindo, meio datilografando uma carta. Perguntei: "Cadê a Bené?", ela disse "viajou". Vem um menino, bate nas minhas costas e pergunta: “O que a senhora está procurando?”. Eu falei: “Nós saímos 15:45h do plenário, e ninguém falou que hoje não tinha sessão". Ele respondeu para mim "ah, moça, a senhora quer o quê?", eu disse "somos domésticas, de todo o Brasil". E ele "a senhora não sabe? Os deputados e senadores cochilaram, e votou". Falei "que cochilaram e votou?". "É, todos os direitos das domésticas, tudo que vocês queriam". Disse "é? Então tá bom. Minha filha, quem tá aî?". Ela "ah, o Lula tá dormindo...", falei "então acorda o Lula, porque quero saber o que a gente vai fazer". Ai lá veio o Lula, meio cochilando, falei: "Olha meu filho, não adianta você estar dormindo, não. Você está aqui na liderança do PT e eu quero saber como é que fica". Ele falou "não, já está tudo encaminhado". Eu perguntei ao rapaz que andava atrás da gente "quem é você?"; e era um correspondente do Jornal do Brasil. Cheguei aqui no Rio e ele tinha feito uma reportagem, então o que a gente não viu, ele escreveu. A gente viu que para a Constituição, as domésticas tinham todos os direitos, ${ }^{25}$ mas não falou, férias - mais um terço -, mas não falou quantos dias. $\mathrm{E}$ levamos mais um ano brigando com os advogados, porque eles diziam que eram 20 dias e a gente dizia que eram 30. Conversando com os patrões, nós conseguíamos manter os 30 dias, mas os advogados diziam que legalmente não era assim. Depois que Lula foi eleito presidente, acho que em 2006, a Lei n. ${ }^{\circ} 1.324$ retroagiu as férias para 30 dias, porque até então não estava. De 1993 para cá, as férias eram de 30 dias acrescidas de um terço. Com a diferença de que elas começariam no dia que começassem. Se era domingo, feriado, as férias eram 30 dias corridos, o que não tinha antes. Daí para cá, a gente ficou pensando - aí veio a Convenção de Genebra, Lei n. ${ }^{\circ} 189 .{ }^{26} \mathrm{O}$ Brasil ratificou, mas não botou em prática até hoje.

21 Ivo Pitanguy (1926-2016) foi um médico brasileiro, considerado um dos melhores cirurgiões plásticos do mundo.

22 Assistente social e governadora eleita do Distrito Federal em 2006. Foi uma das fundadoras do PSDB, partido pelo qual foi filiada até 2018.

23 Ex-dirigente do Sindicato dos Médicos do Rio de Janeiro. Desde 1990, é eleita sucessivamente deputada federal pelo $P C d o B(R J)$.

24 Almir Gabriel (1932-2013) foi um médico e político paraense que passou pela Arena, PDS, PMDB, PSDB e PTB. Foi deputado constituinte, prefeito de Belém, senador e governador do Pará.

25 Os direitos garantidos em 1988 são: salário mínimo, irredutibilidade do salário, $13^{\circ}$ salário, repouso semanal remunerado, férias anuais remuneradas, licença maternidade, aviso-prévio, aposentadoria e o direito de formar sindicatos.

26 Trata-se da Convenção n. ${ }^{\circ} 189$ da OIT, que garante trabalho decente para as trabalhadoras domésticas e proíbe qualquer forma de discriminação legal contra a categoria; adotada em 2011 e ratificada pelo Brasil 
Em 1988, com a Constituição, uma série de direitos para as domésticas são consolidados. Nesse momento, a Associação de Empregadas Domésticas, que virou sindicato, saiu fortalecida? Teve mais interesse por parte da categoria?

Eu acho que não teve mais interesse do que na primeira legislação. 0 pessoal, apesar de ver que os direitos haviam sido ampliados, com a história das férias não ter uma definição, não dá pra dizer que alguém se associou por causa da Constituição, não. Mas começaram os esclarecimentos, as reuniões para falar como eram os novos direitos. Então, eu acho que isso ajudou um pouco. Mas, como disse uma menina para mim: "Quando os direitos chegarem, eles vão chegar para senhora, para mim e para todo mundo; então eu não preciso lutar”. A gente ouviu muito isso. Era um grupinho lá no sindicato lutando por 7 milhões de trabalhadoras domésticas no país. E assim foi.

A senhora diria que, nesse momento, final dos anos 1980, início dos 90, o grupo de domésticas [na direção do sindicato] era mais forte ou mais fraco do que em 1973, quando você foi presidente pela primeira vez?

Era mais fraco. Porque eles achavam que já tinham o que queriam.

Ou seja, o grupo era mais forte durante a ditadura, antes de ser sindicato, quando tinha menos recursos e menos direitos?

Exatamente. [Mais forte como associação] do que depois como sindicato. Agora nós temos menos condições de fazer valer as leis no seu total. Agora mesmo, eu digo que quando completou a colcha de retalho - porque eu digo que a lei das domésticas é uma colcha de retalho -, que todo mundo passou a ter todos os direitos, nós não tivemos ninguém nos sindicatos dizendo assim: "Eu vou me associar". Porque o pessoal viu que estão desempregando as domésticas. Está transformando a categoria em trabalho informal, sem carteira assinada, sem direitos respeitados. ${ }^{27}$

Queria que a senhora falasse um pouquinho sobre a questão geracional. Tem toda essa história de que antes as trabalhadoras chegavam nas casas ainda crianças e hoje a lei proíbe. Além disso, hoje as jovens das camadas populares têm outras opções. As mulheres negras estão ingressando mais na universidade. Dados mostram que muitas trabalhadoras domésticas já têm mais de 60 anos, algumas ainda trabalhando aos 70. Como a senhora vê essa questão da idade? A senhora acha que o trabalho doméstico pode acabar?

Eu não acho que possa acabar, não. Mas, eu acho que essa história de ainda ter empregadas domésticas com essas idades avançadas no trabalho é porque as meninas jovens hoje realmente não querem ser empregadas domésticas. Eu ouço muito isso nos encontros onde eu vou. As meninas preferem vender bala na esquina, vender bijuteria, a trabalhar na casa de patrão. Primeiro, para não ter

em 2018.

27 Trata-se da Lei Complementar n. 150 , de 2015, que vem regulamentar a "PEC das Domésticas" de 2013, e estende quase todos os direitos trabalhistas à categoria, inclusive: obrigatoriedade da carteira assinada, limitação da jornada de trabalho, horas extras, adicional noturno, FGTS, seguro-desemprego, compensação por demissão sem justa causa e negociação coletiva. Apesar de representar um avanço, a lei foi criticada pelos sindicatos por criar uma distinção legal entre a empregada doméstica, a quem se aplicam todos os direitos, e a diarista, que trabalha até dois dias por semana para o mesmo empregador e para quem a assinatura da carteira não é obrigatória. A diarista se torna assim uma trabalhadora autônoma, não contemplada pelos novos direitos, e, de fato, o número de diaristas vem aumentando desde 2015. 
patroa e não ter ninguém para ditar ordens, e segundo, porque elas acham muito humilhante ficar lá dentro daquelas casas e não poder olhar o universo que tem aqui fora.

Eu queria fazer uma última pergunta. Há uma família que a senhora escolheu em Nova Iguaçu. A senhora se mudou para Nova Iguaçu, passou a atuar no sindicato de lá. Eu queria que a senhora falasse um pouco mais sobre isso.

Bom, essa família que eu adotei em Nova Iguaçu e que me adotaram, já com 20 e poucos anos, foi porque nesse grupo de babás tinha duas meninas que eram dessa família. Uma morreu e a outra está viva. E a gente ficava junto, e no dia que eu tinha folga elas me levavam lá para a casa delas. Um dia, eu disse assim: "Dona Maria, a senhora não quer me adotar, não?". Ela disse assim, "ah minha filha, você já vem para cá sempre”. Falei, "então é mãe, né? Não vou te chamar mais de dona Maria, vou chamar de mãe". E assim a gente ficou e foi assim que eu fui para lá. Então, aquela família, que eu digo minha família e que eu tenho tataranetos nela hoje. O quintal que eu moro era da bisavó deles, não era da minha bisavó que morreu lá no Maranhão, cercada de todas nós com 123 anos. Ela tinha um quintal de $100 \times 10 \mathrm{~m}$, com oito casas. A casa que eu moro era a casa que morava Maria Ondina com o marido, as duas filhas e cheguei como a terceira. A Marli, a Marlene e eu. Quando a mãe morreu, a Marli tinha arranjado um sujeito que tinha duas crianças. Um dia, eu estava no trem - a mãe tinha morrido há pouco tempo - e eu vi aquela neguinha sentada lá naquele banco com aquelas criancinhas, e eu disse, "ué, parece minha irmã". Fui lá e perguntei, "o que você tá fazendo aí?". [Ela respondeu] "ah, fulano não pagou o aluguel e a dona da casa botou a gente na rua”. Falei, "é? Fica aí”. Atravessei o Centro até o outro lado da [Via] Dutra, chegando lá, o pai estava em casa. Falei, "pai, encontrei a sua filha lá no jardim com as crianças”, [ele] “problema é dela”. Falei, “não, problema é nosso!”. Liguei e falei: "Marlene, eu vou dividir a nossa casa com a Marli". Ela disse: "Problema é seu porque eu já estou casada, não tenho mais nada a ver: é você e o pai”. Então, falei pro pai "eu trabalho, ganho bem, vou comprar material pro senhor fazer um quarto, cozinha, banheiro e área. Eu não quero sala porque eu não venho para casa, então não recebo visitas. Amanhã eu vou mandar o material, mas hoje eu vou voltar lá na estação e trazer a sua filha para cá. Vou dar o meu quarto para ela e como eu não fico aqui, vou voltar pro meu trabalho". E foi assim que eu fiz. Ela foi com aquelas duas crianças. Ele fez minha cozinha, banheiro e um pedacinho que era como se fosse um quarto, que eu falei para ele que quando eu chegasse, eu jogava um colchonete e dormia, mas eu nunca fiz isso. Primeiro, porque eu era muito esquecida, depois, que ele não era meu pai de verdade e era muito mulherengo; "se eu venho para cá, vão dizer que eu estou dormindo com ele, não venho". Eu não ia para casa, e ela ficou.

Dividi a casa, deixei uma porta aberta que dava para o meu pedaço e era para eles cuidarem dele, que o pai já estava com idade. Só que eles não cuidavam e ainda catavam as coisas dele. Eu ia final de semana, fazia comida para a semana toda e deixava congelada. E aí eu descobri que ele tinha uma amante! Só que uma que ele tinha há muitos anos. Hoje, por sinal, eu gosto muito dela. É, a mãe já morreu, que adianta ficar brigando agora que nem minha irmã? Não, minha filha, você lê a Bíblia? Ela diz que você tem que perdoar, se não, não adianta ler a Bíblia. Aí, a Marli ficou naquele pedaço que eu dei para ela - essa porta eu fechei há pouco tempo e eles ficaram com raiva de mim por alguns dias. Agora são os netos e bisnetos, porque a Marli e o marido já morreram; tem o filho e a filha. O filho arrumou uma 
mulher, tem cinco filhos, uma especial. Agora tem uma neta que bate lá no meu portão: “Vó, tem bala? Tem biscoito?”. Uma coisinha dessas, bem naniquinha. E a menina arranjou um cara que fez uma casa para ela na frente. Tem oito filhos, três netos. A casa que eu moro, eu queria trocar com a primeira casa que era da minha tia, lá em cima, irmã da minha mãe, mas os filhos não quiseram. Então a minha casa é a dois, mas até chegar na minha são três. Quem paga o imposto do quintal sou eu. Agora chegou uma neta, fez um casarão, foi na prefeitura e foi falar para mim "tia, eu quero pagar o imposto da minha casa". Falei "então em setembro vamos na prefeitura; pega os documentos de todo mundo que na prefeitura a gente autoriza cada um pagar o seu pedaço, mesmo sem ser desmembrado. Lembrando que isso aqui era da minha bisavó, não era de vocês não, preste bem atenção nisso". Então, essa é a minha família.

Recebido em 13/5/2019 Aprovado em 12/6/2019 
